\title{
Triceratium moreirae sp. nov. AND Triceratium dubium (TRICERATIACEAE - BACILLARIOPHYTA) FROM ESTUARINE ENVIRONMENTS OF SOUTHERN BRAZIL, WITH COMMENTS ON THE GENUS Triceratium C. G. EHRENBERG
}

\author{
FERNANDES, L. F. ${ }^{1}$ and SOUZA-MOSIMANN, R. M. $\mathrm{de}^{2}$ \\ ${ }^{1}$ Departamento de Botânica, Setor de Ciências Biológicas, Universidade Federal do Paraná, Centro Politécnico, \\ C.P. 19031, Jardim das Américas, CEP 81531-970, Curitiba, Paraná, Brazil \\ ${ }^{2}$ Universidade Federal de Santa Catarina, Horto Botânico, Campus Universitário, Trindade, C.P. 476, \\ CEP 88010-940, Florianópolis, Santa Catarina, Brazil \\ Correspondence to: Luciano F. Fernandes, Departamento de Botânica, Setor de Ciências Biológicas, Universidade \\ Federal do Paraná, Centro Politécnico, C.P. 19031, Jardim das Américas, CEP 81531-970, Curitiba, Paraná, \\ Brazil, e-mail: lucfel@bio.ufpr.br \\ Received November 11, 1999 - Accepted May 10, 2000 - Distributed February 28, 2001
}

(With 36 figures)

\begin{abstract}
A new species of Triceratiaceae is described for estuarine environments of Southern Brazil. The valve of Triceratium moreirae sp. nov. is triangular with elevations bearing ocellus and a rimoportula in their basis. The valvar surface has robust pseudoloculi, circular to polygonal, each one confining a group of areolae arranged in a typical pattern. A central larger areola is surrounded by 5-8 smaller areolae, and they are poroidal with domed cribra. A septum emerges from the valvocopula, having the base reinforced by ribs and the margins folded to the innerside of the valve. The new species is compared to the closely related diatom Triceratium dubium, which has the same pattern of areolar disposition, formation of septum and pseudoloculi. The main diferences in relation to T. moreirae are: rimoportulae intercalated to ocelli and with a characteristic morphology (spinules on the edge of the external aperture), and more elongated elevations with a constriction. Some criteria used for the classification of categories into the Triceratiaceae are also discussed, and we propose that the type of areola (poroidal with cribra) be included in the circumscription of Triceratium.
\end{abstract}

Key words: taxonomy, diatom, Triceratium, estuary, mangrove, Southern Brazil.

\section{RESUMO}

Triceratium moreirae sp. nov. e Triceratium dubium (Triceratiaceae - Bacillariophyta) de ambientes estuarinos do Sul do Brasil, e comentários sobre o gênero Triceratium C.

\section{G. Ehrenberg}

Uma nova espécie da Família Triceratiaceae é descrita a partir de amostras coletadas em manguezais do Sul do Brasil. A valva de Triceratium moreirae sp. nov. é triangular com elevações portando ocelos e uma rimopórtula robusta na base de cada elevação. A superfície valvar apresenta pseudolóculos robustos circulares a poligonais que delimitam aréolas com poros cribrais hemisféricos. Estas últimas estão arranjadas em um padrão típico, em que uma aréola central maior está circundada por 5-8 aréolas menores. A valvocópula emite um septo reforçado por costelas, e sua extremidade é dobrada para o interior. A nova espécie é comparada com a diatomácea Triceratium dubium, a qual tem o mesmo padrão de disposição de aréolas, formação de septo e pseudolóculos. Entretanto, as principais diferenças em relação à Triceratium moreirae são: rimopórtulas alternadas aos ocelos e com morfologia bem característica, e elevações mais alongadas com uma leve constrição. Alguns critérios utilizados na 
classificação das espécies de Triceratiaceae também são discutidos, e sugerimos que o tipo de aréola (poroidal com cribra) seja incluído na circunscrição de Triceratium.

Palavras-chave: taxonomia, diatomácea, Triceratium, estuário, manguezal, Sul do Brasil.

\section{INTRODUCTION}

In the classical systems of classification, the taxonomy of centric diatoms bearing an "elevation" or "process" was based on the polarity (bipolar to multipolar), the presence of spines and the growth forms of the thallus, giving rise to a considerable confusion in the literature (see Ross \& Sims, 1971 for a historical review). Since the development of sophisticated techniques for the observation of diatom frustules (e.g. electron microscopes), the taxonomic position and the validity of genera presumed quite allied like Triceratium, Trigonium, Biddulphia, Odontella, Sheshuskovia, Amphitetras among others, have been rediscussed. Many changes in the nomenclature and the classification of that group have been also proposed. It was found that taxa early considered closely related were, actually, quite different one to another, and they should be placed in other taxonomic categories (Glezer, 1975; Hoban, 1979, 1983; Ross \& Sims, 1971, 1973; Sar, 1989).

The presence of an ocellus or pseudocellus, the number and disposition of rimoportulae, the valve polarity and the presence of pseudoloculi are the criteria currently used for the separation of taxonomic categories within the Families Triceratiaceae and Biddulphiaceae sensu Round et al. (1990).

In Triceratiaceae, the genus Triceratium comprises marine diatoms with living and fossil species, and VanLandinghan (1978) recognized more than 500 valid taxa. In our understanding, shared with Sims \& Ross (1990), Triceratium is characterized by (i) valves with elevations bearing ocelli, (ii) valvar surface with pseudoloculi, sometimes poorly developed, (iii) mantle projected outwards in the valvar margin and (iv) valves generally tripolar, rarely bipolar or tetrapolar.

In this work we described the new species Triceratium moreirae, regularly reported in the floristic surveys carried out in mangroves of Southern Brazil under the name Triceratium sp. (Felício-Fernandes et al., 1994; Fernandes et al., 1990, 1999; Souza-Mosimann, 1984, 1985, 1988).
The closely related species Triceratium dubium Brightwell also was investigated due to its very similar features when compared to T. moreirae. The former is a temperate to tropical species found in shallow waters of the world oceans (Foged, 1975; Hustedt, 1927-66; Ricard, 1987; Fernandes et al., 1990). From our results and from the literature, we compared the valve structures of some species, and discussed some criteria used to circumscribe the genus Triceratium.

\section{MATERIAL AND METHODS}

Material for analyses was obtained from two estuaries of Southern Brazil: (i) Paranaguá Bay $\left(25^{\circ} 25^{\prime} \mathrm{S}-25^{\circ} 35^{\prime} \mathrm{S}\right.$ and $\left.48^{\circ} 20^{\prime} \mathrm{W}-48^{\circ} 45^{\prime} \mathrm{W}\right)$, Paraná State, an estuarine complex with $117 \mathrm{~km}^{2}$ and average depth of 4.3 meters; and (ii) Ratones river estuary ( $27^{\circ} 15^{\prime} \mathrm{S}-27^{\circ} 29^{\prime} \mathrm{S}$ and $\left.48^{\circ} 30^{\prime} \mathrm{W}-48^{\circ} 40^{\prime} \mathrm{W}\right)$, Santa Catarina State, with $17 \mathrm{~km}^{2}$ and average depth of 1.8 meters. Both the estuaries are influenced by the subtropical climate (Cfa) with two welldefined seasons: rainy in summer and dry in winter, with annual average rainfall of $1,988 \mathrm{~mm}$. Salinity varies from 12 to 34 , range of water temperature $18-30^{\circ} \mathrm{C}$, and the annual average of semidiurnal tides is $2.2 \mathrm{~m}$. Mangroves, salt marshes of Spartina spp. and tidal flats are the main environments bordering the estuaries.

Plankton samples were collected using standard plankton net $25 \mu \mathrm{m}$ mesh apertures. Samples were preserved with buffered formaldehyde (2\%) and prepared for light and electron microscopy according to Hasle \& Fryxell (1970). An aliquot of the samples was just only washed with distilled water, and specimens directly picked up to SEM aluminum stubs. Permanent slides were prepared using Naphrax as mounting medium. Light microscopy (LM) was performed in an Olympus BX40 microscope using 100x oil immersion objective. For scanning electron microscopy (SEM) samples were air-dried on coverslips mounted on aluminum stubs with conductive paint, coated with 16-20 $\mathrm{nm}$ gold and examined at $15-25 \mathrm{kV}$ accelerating voltage in a Phillips model XL30 scanning electron microscope. 
The descriptive terminology followed Ross et al. (1979) and Round et al. (1990).

\section{RESULTS}

Triceratium moreirae sp. nov. L. F. Fernandes et Souza-Mosimann (Figs. 1-21)

Latin Diagnosis: Valvae tripolares exhibentes elevationes in verticibus et portantes unam rimoportula et unum ocellus. Superficies valvares convexa exhibens pseudoloculi vel circulares vel poligonales, involventes grupos portantes 6-9 areolae cribales. Grupus unusquisque praesentat areolam centralen maiorem circumdatam 5-8 areolae minoribus. Areolae disponuntur radialiter. Rimoportula exhibens tubum externum roboratum costulis siliceis et oram rasa. Fissura labiata interna circumdata spissitate siliceosa elliptica. Saeptum transversale ad valvocopulam exhibens extremitatem plicatam ad valvae interiorem. Saepti basis roborata costulis. Latus 47-61 um longum; axis pervalvaris 27-33 $\mu \mathrm{m}$ longus.

Diagnosis: Valves tripolar; corners with elevations, each one bearing one rimoportula and one ocellus. Valvar surface convex, with circular to polygonal psudoloculli surrounding a group of 6-9 domed cribral areolae. Areolae radially disposed on the valvar surface. External tube of rimoportula reinforced by silica ribs, and with smooth edges. Internal labiate fissure bordered by a thickened elliptical rim. Septum in a transverse position in relation to the valvocopula, with the base reinforced by ribs, and the edge folded to the inner side of the valve. Length of size 47-61 $\mu \mathrm{m}$; pervalvar axis 27-31 $\mu \mathrm{m}$.

Holotype: slide n. 12553; FLOR Herbarium at Federal University of Santa Catarina, Brazil

Etymology: homage to Dr. Hermes MoreiraFilho, a pioneer and the disseminator of the diatom taxonomy in Brazil.

Type locality: Ratones River estuary; salinity 12-34, water temperature $18-30^{\circ} \mathrm{C}$.

Description LM: Valves are triangular with straight or concave sides (Figs. 1-4); length of size 47-61 $\mu \mathrm{m}(\mathrm{n}=23)$; pervalvar axis $27-31 \mu \mathrm{m}(\mathrm{n}=$ $4)$. An elevation with one ocellus and one rimoportula appears in each corner. The valvar surface is areolate; areolae in radial disposition. The pseudoloculi are polygonal with irregular contour. In the central region of the valve they are larger than in the margin (Figs. 3-4). A deeply convex mantle with elongated pseudoloculi in its base is seen in lateral view. The cingulum bears broad areolae in transverse rows (Fig. 6). The valvocopula shows a striated septum, well-developed (Fig. 5).

Description SEM: Frustules are trihedrical having straight to slightly concave sides (Figs. 7$8)$. Valves are tripolar, with elevated corners projected outwards (Fig. 9). The valvar surface is slightly convex, covered by nearly circular pseudoloculi (Figs. 7-11), whose are modified in siliceous bars in the base of the elevation (Figs. 9, 13). In the base of the mantle, the pseudoloculi are elongated (Fig. 10). In internal view, the pseudoloculi appear quadrangular to polygonal (Fig. 12). Each pseudoloculus has 1.2-2.5 $\mu$ m diameter, and its walls bear short spines. The valve structure is composed of poroidal areolae with domed cribra (12-16 in $10 \mu \mathrm{m}$ ), radially arranged (Figs. 11-12). Areoale are enclosed by walls of pseudoloculi, in such a way to compose clusters of 5-8 small areolae with many tiny cribral pores. These latter surround a larger central areola with 6-10 cribral pores (Figs. 11-12). The three corners of the valve have elevations bearing ocelli. Ocellus is circular, 2.0-3.2 $\mu \mathrm{m}$ diameter, with porelli in concentric rows surrounded by a thickened rim (Figs. 10-13). A rimoportula is located at the base of the elevation, having an external tube reinforced by projected ribs (Figs. 13-14).

In the inner side, there is an elongated fissure with elliptical rim (Figs. 15-17). In some valves, we observed two rimoportulae in one unique elevation (Fig. 16); or one marginal rimoportula in the mantle, on the middle distance between the corners. Mantle is deeply convex (Figs. 8-10), with a basal row of elongated pseudoloculi. A thin siliceous ridge is placed on the mantle edge, bordering this latter with the valvocopula (Fig. 10). The cingulum has 2-3 bands composed of 7-9 simple poroids in transverse rows (Fig. 9). The valvocopula shows a transverse septum reinforced in its base by ribs (Figs. 20-21). Its edge is folded to the inner side of the valve (Figs. 18-19).

\section{Triceratium dubium Brightwell (Figs. 22-36)}

Description LM: The hexagonal valve has undulated margins (Figs. 22-23) and concave sides; length 42-50 $\mu \mathrm{m}$ from ocellus to ocellus $(\mathrm{n}=9)$; $35-40 \mu$ m pervalvar axis $(n=3)$. 

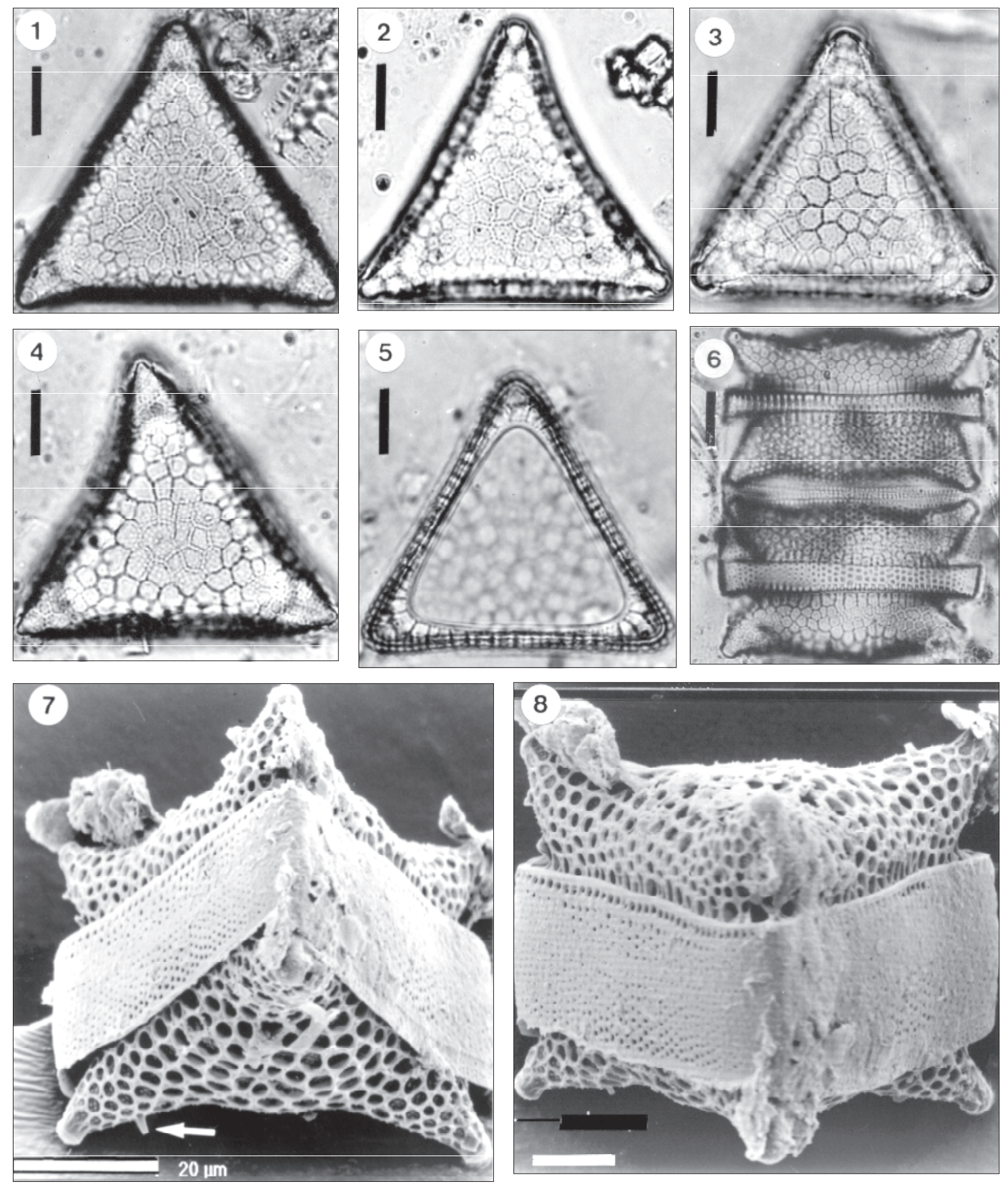

Figs. 1-8 - Triceratium moreirae, LM (Figs. 1-6, holotype slide) and SEM (Figs. 7-8). 1-4 - Valvar views, showing different arrangements of areolae and pseudoloculi. Scale bars $=10 \mu \mathrm{m} . \mathbf{5}-$ Focus on the septum, revealing its chambers. Scale bar $=$ $10 \mu \mathrm{m} .6$ - Two frustules in girdle view. Note marked valvocopulae and the deeply convex mantle. Scale bar $=10 \mu \mathrm{m}$. Figs. 7-8. Views of entire frustules, evidenciating the cingulum and the pseudoloculi. A rimoportula is indicated (arrow) in the Fig. 7. In the Fig. 8 , note elongated pseudoloculi associated to the mantle edge. 7 - Scale bar $=20 \mu \mathrm{m} .8-$ Scale bar $=$ $10 \mu \mathrm{m}$. 

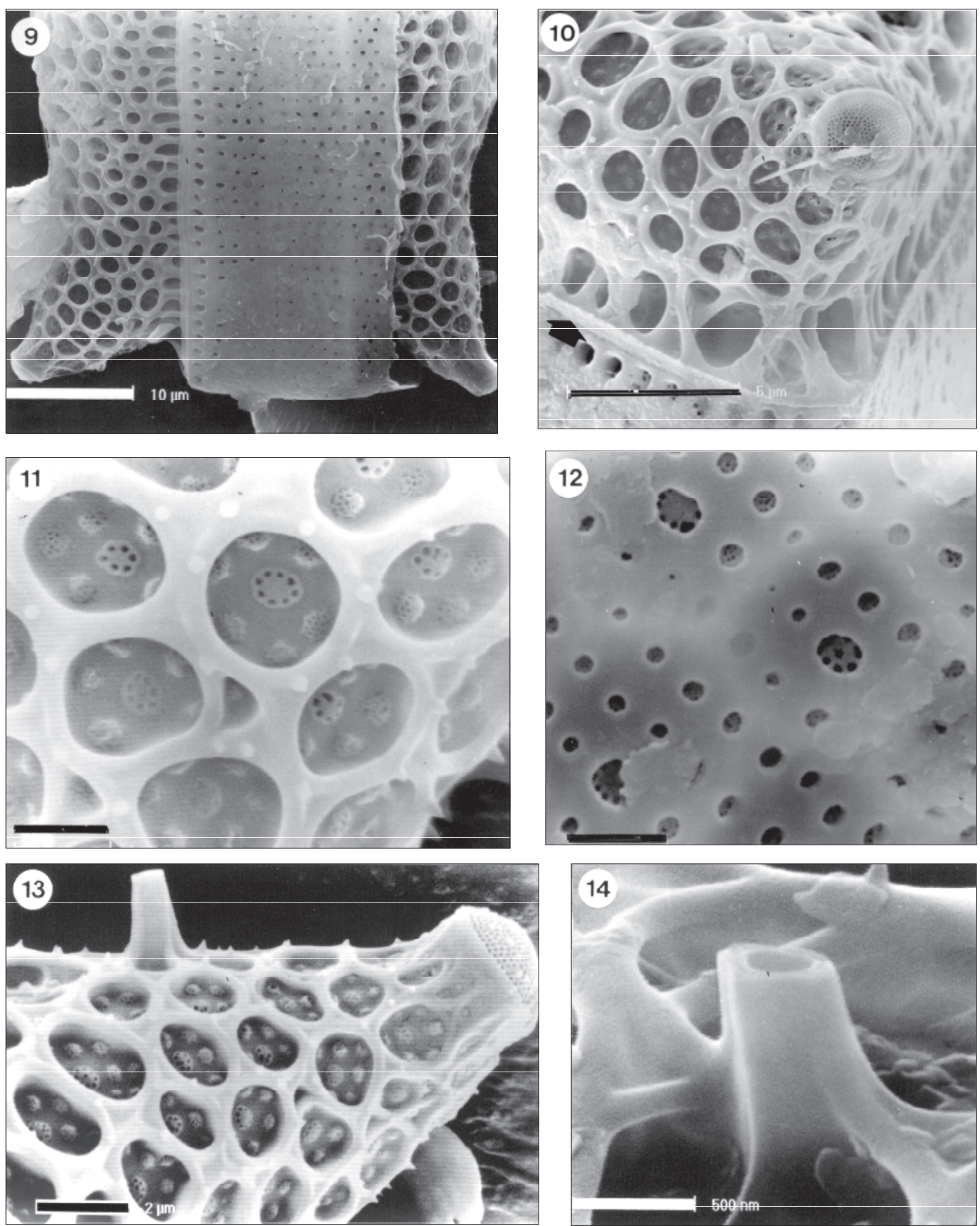

Figs. 9-14 - Triceratium moreirae, SEM. 9- Frustule in girdle view, showing cingulum with transverse rows of single pores. Note pseudoloculi on the mantle. Scale bar $=10 \mu \mathrm{m} .10-$ Corners of the valve. Elongated pseudoloculi on the base of the mantle are visible. Also illustrated is the ridge on valvar edge (arrow). Note the ocellus and its associated rimoportula on the elevation. Scale bar $=5 \mu \mathrm{m} .11-$ Detail of areolae in external view. A large central areola is surrounded by small areolae. Scale bar $=1 \mu \mathrm{m} .12-$ Internal view of valve. Note radial disposition of areolae. Scale bar $=1 \mu \mathrm{m} . \mathbf{1 3}-$ Elevation of valve, illustrating rimoportula and ocellus. Rimoportula is reinforced by ribs. Note small spines. Scale bar $=2 \mu \mathrm{m}$. $\mathbf{1 4}-$ Close of external aperture of rimoportula, illustrating its circular aperture inside a tube. Scale bar $=500 \mathrm{~nm}$. 

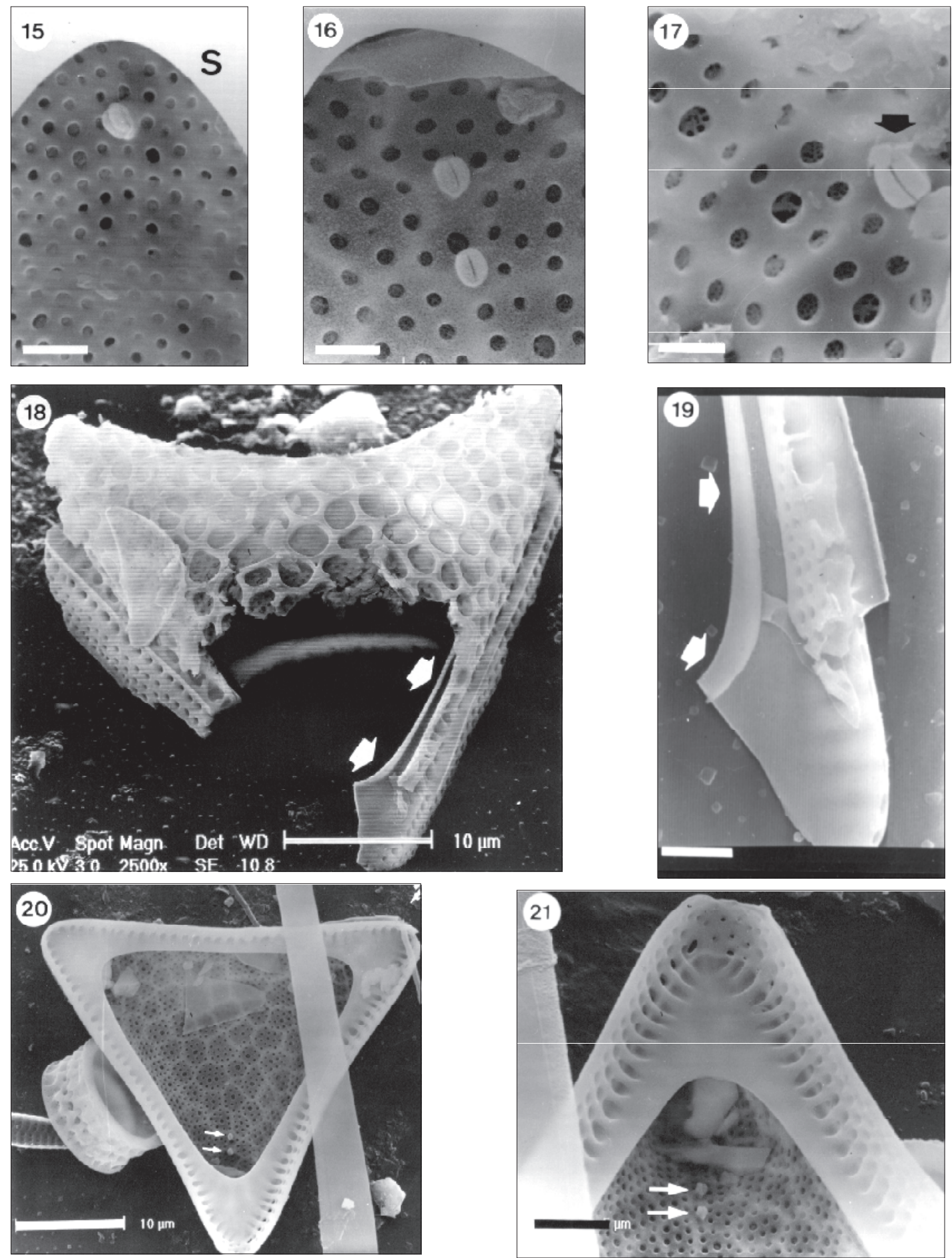

Figs. 15-21 - Triceratium moreirae, SEM. 15-17 — Internal views of rimoportulae near the septum (S), revealing their variability in morphology and number. In the $\mathbf{1 7}$ - note radial disposition of areolae; rimoportula is indicated by an arrow. Scale bars: Figs. 15 and $16=1 \mu \mathrm{m}$; Fig. $17=1 \mu \mathrm{m}$. 18 - Broken valve, showing the elongated septum (arrows) of the valvocopula. Scale $b a r=10 \mu \mathrm{m} .19-$ Detail of valvocopula with poroidal areolae and folded septum (arrows). Scale bar $=2 \mu \mathrm{m} . \mathbf{2 0}-$ General internal view of valve, with conspicuous septum. Note two rimoportulae (arrows), and radial disposition of areolae. Scale bar $=10 \mu \mathrm{m} . \mathbf{2 1}$ - Detail of septum, reinforced by ribs. Note two rimoportulae (arrows) near the corner. Scale bar $=5 \mu \mathrm{m}$. 

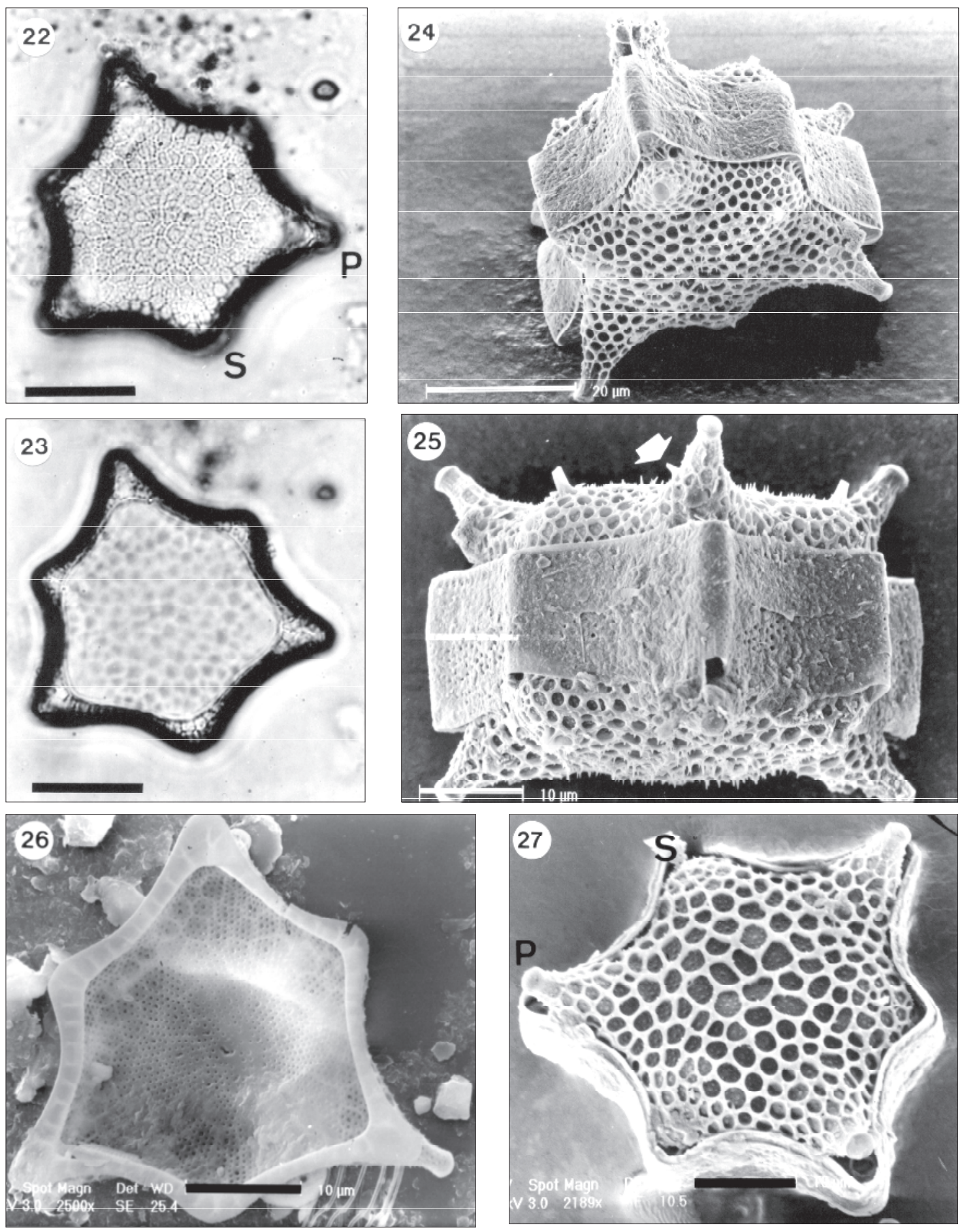

Figs. 22-27 - Triceratium dubium, LM (Figs. 22-23) and SEM (Figs. 24-27). 22 - Valvar view, showing pseudoloculi and areolae on the surface. Note the three primary $(\mathrm{P})$ and secondary $(\mathrm{S})$ corners. Scale bar $=10 \mu \mathrm{m} . \mathbf{2 3}$ - Valvar view, focus on septum with small chambers. Scale bar $=10 \mu \mathrm{m} . \mathbf{2 4 - 2 5}$ - Entire frustule in different views. Note ondulations and their associated rimoportulae, and spines of valvar surface. An additional rimoportula is visible on the base of an elevation (arrow). Scale bars: Fig. $24=20 \mu \mathrm{m}$; Fig. $25=10 \mu \mathrm{m} . \mathbf{2 6}-$ Internal view of the valve, evidenciating a chambered septum. Scale bar $=10 \mu \mathrm{m} .27-$ External view of the valve. Primary $(\mathrm{P})$ and secondary $(\mathrm{S})$ corners are indicated. Scale bar $=10 \mu \mathrm{m}$. 

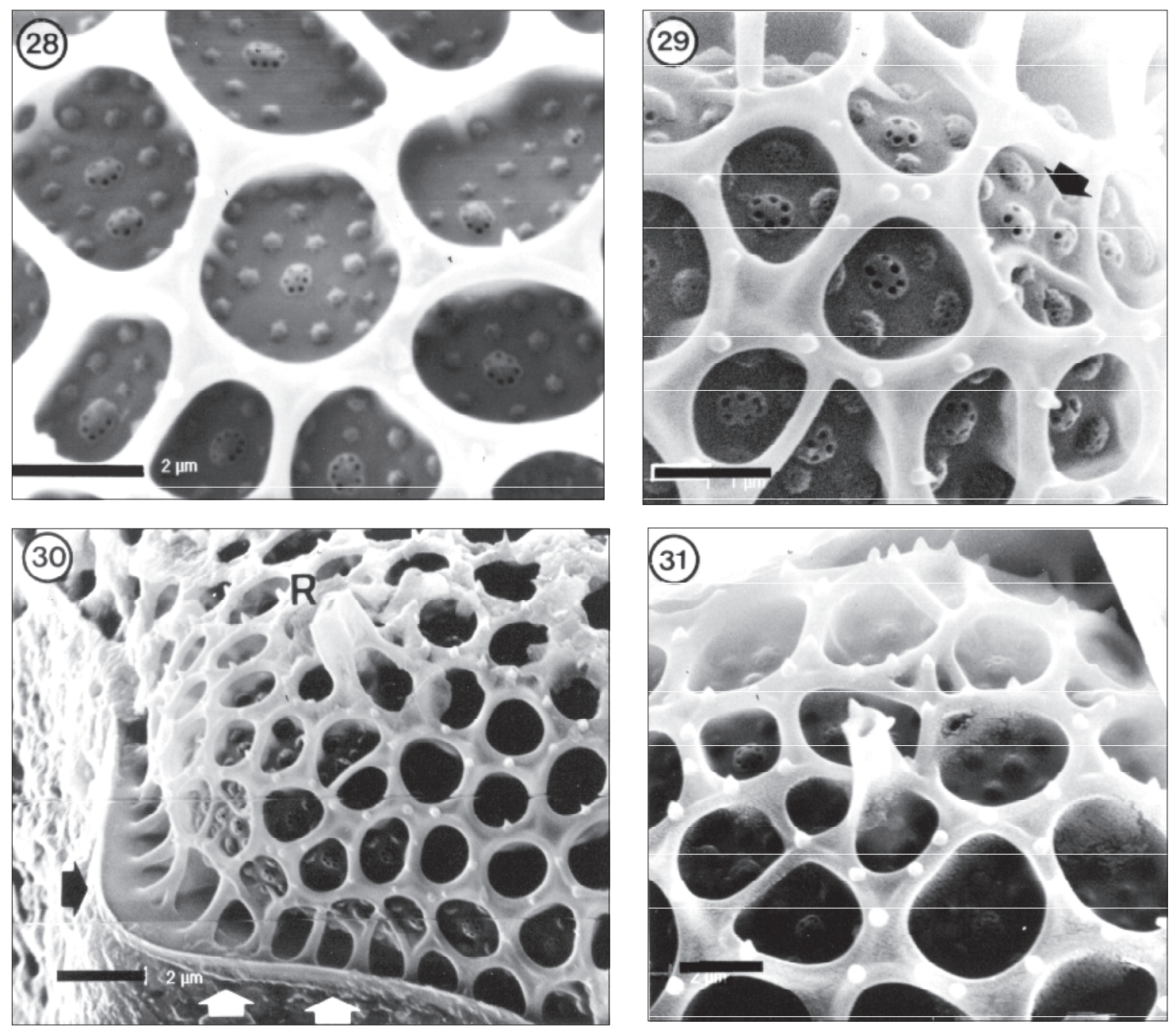

Figs. 28-31 - Triceratium dubium, external views of the valve, SEM. 28 - Pseudoloculi and areolae on central region of the valve. Scale bar $=2 \mu \mathrm{m} . \mathbf{2 9}-$ Detail of areolae with domed cribra (arrow) in the marginal region. Scale bar $=1 \mu \mathrm{m}$. 30 - Structure of the mantle in a secondary corner, with a broken rimoportula $(\mathrm{R})$. Note the elongated pseudoloculi, and the ridge of mantle edge (arrows). Scale bar $=2 \mu \mathrm{m} .31-$ External tube of rimoportula with three spines. Scale bar $=1$ $\mu \mathrm{m}$.

There are three larger corners possessing the ocelli, and three secondary corners (smaller and short) bearing the rimoportulae. Valvar surface is areolate; areolae radiating from the valve center. Pseudoloculi are conspicuous, polygonal. Valvocopula bears a transverse reticulate septum (Fig. 23).

Description SEM: Frustules are hexagonal having three main corners bearing the ocelli, and three secondary corners with the rimoportulae (Figs. 24-25). The valvar surface is convex and undulated, composed of circular to polygonal pseu- doloculi, larger at the center and smaller at the marginal region of the valve (Figs. 27-29). Pseudoloculi enclose areolae in clusters, each cluster having 10-14 areolae at the central region of the valve, and 4-7 areolae in the marginal ones. Many short spines are scattered over the valve, and they emerge from the walls of pseudoloculi (Figs. 25, 36). Areolae are poroidal with domed cribra (Figs. 28-29). Two types occur: (i) a larger central areola with 6-8 cribal pores which is surrounded by (ii) 4-19 smaller areolae, each one with many tiny cribral pores (Figs. 28-29). 

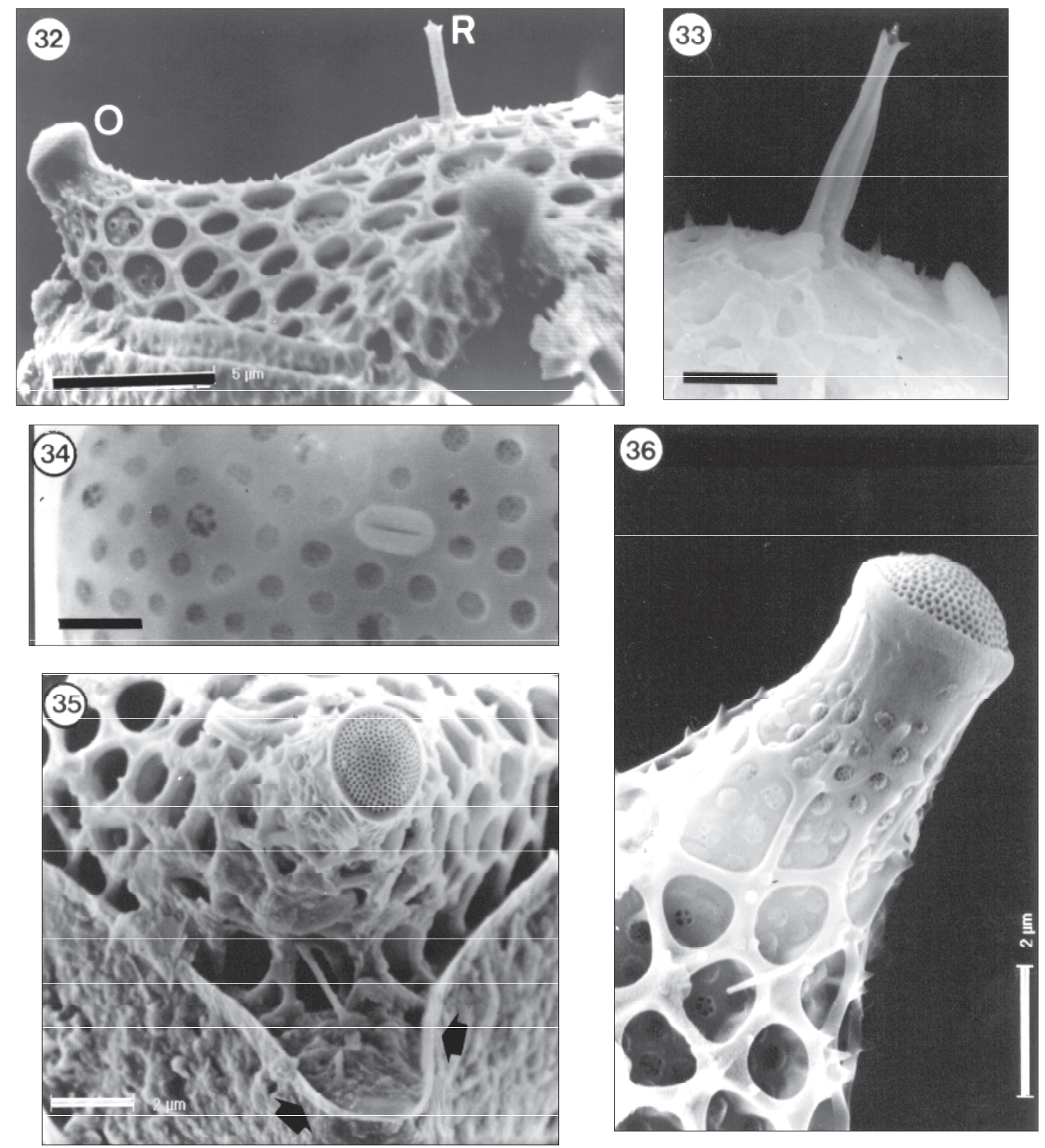

Figs. 32-36 - Triceratium dubium, SEM. $32-$ General view of ocellus $(\mathrm{O})$ and rimoportula (R). Scale bar $=5 \mu \mathrm{m} .33-$ External view of rimoportula. Scale bar $=2 \mu \mathrm{m} .34-$ Internal view of rimoportula. Note radial disposition of areolae. Scale bar $=1 \mu \mathrm{m} .35-$ Ocellus bearing porelli in two patterns of rows. Note ridge on the mantle edge (arrows). Scale bar $=2$ $\mu \mathrm{m} .36$ - Ocellus in lateral view. Its base is constricted, and areolae appear not surrounded by pseudoloculi. Scale bar = $2 \mu \mathrm{m}$.

Rimoportulae are placed on the secondary corners, one per corner (Figs. 30-33). In some valves we observed a rimoportula in the base of the elevation which bears the ocellus (Fig. 35). Its morphology is somewhat variable. The external aperture may be short or fairly elongated, reinforced or not by ribs, but always having three spinules in its apex (Figs. 31-33). Rimoportula opens to the inside by means of a labiate fissure bordered by elliptical rim (Fig. 34). Three ocelli 
appear on the edge of the elevations located at the main corners (Figs. 24-25). Each ocellus has 1.9$2.1 \mu \mathrm{m}$, and bears a circular rim encircling rows of porelli, distributed in two patterns: marginal radial rows in the margin and convex rows in the center (Figs. 34-35). The base of the ocellus is slightly constricted (Figs. 32, 36). Mantle is convex, having a basal row of elongated pseudoloculi (Fig. 30). Its base is projected outwards, and the edge has a delicate ridge parallel with the cingulum (Figs. 30, 35). Cingulum has 1-2 bands with poroidal areolae in transverse rows (Figs. 24-25). Valvocopula shows a septum with convex surface and, apparently, divided into internal chambers (Fig. 26).

\section{DISCUSSION}

The species studied in this work show similarities one to another as the general morphologies of ocellus and pseudoloculus, the poroidal areolae bearing domed cribra, the presence of septum and the spines. The main differences are associated to the position and structure of rimoportulae, the morphology of elevations, and the undulations of the valvar edge in T. dubium, absent in T. moreirae. Despite the differences, both the species clearly compose a closely allied group.

In his instigating work on diatom phylogeny, Simonsen (1979) separated the 'Biddulphiineae' (including taxa with ocellus and pseudocellus) in three distribution patterns regarding number and disposition of rimoportulae: (i) one central or subcentral rimoportula, (ii) a central cluster of rimoportulae and (iii) one or more rimoportulae per pole or a marginal row along the mantle edge. In this respect, $T$. moreirae could be placed in the third pattern, having one rimoportula in the base of the elevation. It is important to remind we found some valves with an additional marginal rimoportula in the middle distance between the ocelli. Such a finding gives rise to questionings on the validity of this criterion, mainly when one aims to discuss the affinities between taxa of biddulphioid and eupodiscoid diatoms. On the other hand, the rimoportulae of T. dubium show a pattern of distribution totally dissimilar from those summarised by Simonsen (1979). They are marginal and intercalated to the ocelli, that is, not in the basis of the ocelli. However, as for T. moreirae, we again found an anomaly in the rimoportula positioning of some valves, which was on the base of the elevation, slightly displaced to the margin. Yet about the rimoportula in Triceratium, we have the following possibilities related to its number: two [T. dictyotum Sims \& Ross, 1990 (= Biddulphia reticulata Roper)], three (T. dubium, T. moreirae, T. pulvinar, A. S. Schmidt, T. unguiculatum Greville) and more than three (T. favus Ehrenberg, T. robertsonianum Greville).

The internal aperture of the rimoportula of T. moreirae and T. dubium is an elongated fissure like in almost the species studied in the literature, but the siliceous rim around the fissure is more variable. It could be elliptical like in T. moreirae and T. dubium, spherical in T. favus, or papillose with a buttress-like projection in $T$. pulvinar and T. unguiculatum. The external opening of T. moreirae is a short tube, while in T. dubium it is usually elongated and bears spinules at the apex. This feature was not yet observed in other Triceratium taxa, but only in some representatives of Odontella (Triceratiaceae) like O. aurita and $O$. sinensis. However, the internal labiate structure in these taxa is quite distinct from that of T. dubium, being sessile and weakly thickened (Round et al., 1990).

Well-developed pseudoloculi enclosing the areolae in clusters were recorded on the valvar surface of T. moreirae and T. dubium. The pseudoloculus is an important diagnostic character of the genus, and we define it as a chamber bordered by circular to polygonal silica walls on the external valvar surface. Ross \& Sims $(1971,1972)$ and Sims \& Ross (1990) adopt the same concept, but not Round et al. (1990). These authors seem to interpret the pseudoloculus in Triceratium as taking part in the structure of a loculate areola, which would be composed of a large external foramen, a chamber (our pseudoloculus) and internal cribra separated in groups.

T. dictyotum is another species that deserves consideration. Except for its bipolarity and position of the rimoportulae (Ross \& Sims, 1971, 1972), its valve structure is closely related to T. moreirae and $T$. dubium due to the presence of poroidal areolae with domed cribra, and the general layout of pseudoloculi and ocelli. Unfortunately, there are no descriptions of the rimoportula in T. dictyotum in the literature, hampering a further com- 
parison between the three species. In this context, another related species could be Cerataulus smithii, in which the valve shows pseudoloculi, spines and ocelli with similar morphology to those of T. dictyotum, T. dubium and T. moreirae. Such observations pose the necessity of revision in this group of bipolar/tripolar pseudoloculate diatoms.

The only other related species to T. moreirae found in the classical and recent literature was $T$. japonicum A. Schmidt (Schmidt, 1885; Tf. 84, Fig. 17). However, pseudoloculi in this diatom are more regular and smaller than those of $T$. moreirae do. In addition, the illustration of A. Schmidt does not show the marginal septum, found in all the valves of T. moreirae.

All of the Triceratium taxa cited above bear poroidal areolae with cribra composing the valve structure (Hustedt, 1927-1966; Ross \& Sims, 1971, 1972; Sims \& Ross, 1990; this work). Therefore, we propose this feature take part in the diagnosis of the genus.

If one accept the criteria to delimitate the genus Triceratium discussed above, so the type species Triceratium favus could be the farthest taxa from its circumscription. It has a marginal row of rimoportulae, complex valve structure and special loculate areolae (Miller \& Collier, 1978; Round et al., 1990), although these latter could be interpreted as pseudoloculi placed on cluster of poroidal areolae, more elaborate than in other species. (In the case of this point of view prevails, pseudoloculi would actually be a unifying feature of Triceratium.)

In addition, as we commented above, the rimoportula of T. favus is totally different from the other species, its external aperture being spatulate and internal one hemispherical (Miller \& Collier, 1978). On the mantle edge of T. favus there is a specific 'circumferential canal' with small pores opening to the inside (Miller \& Collier, 1978). A very similar structure, called 'marginal circumferential tube', was found in Fryxelliella A. K. S. K. Prasad (Fernandes, submitted; Prasad et al., 1997), an eupodiscacean genus with three ocelli intercalated to marginal rimoportulae, and lacking pseudoloculi. It seems that the two structures are homologous, indicating more affinity between Triceratium and Fryxelliella than previously believed. At least, T. favus and Fryxelliella spp. could represent an evolutionary line apart from the other genera of Triceratiaceae.
Fernandes (submitted) investigated the existence of a marginal canal also in Eupodiscus, but it could not be neither confirmed nor rejected. So, the author defended to await further investigations to separate or not Fryxelliella from Triceratiaceae, an idea suggested by Prasad et al. (1997) based on the presence of the marginal tube.

Acknowledgments - We wish to express our gratitude to Dr. Daura R. E. Stofella (Centro de Microscopia Eletrônica UFPR) and Dr. Maurício P. Cantão (LACTEC/Cooperativa Paranaense de Energia Elétrica) for their assistance in using of the SEM. This work was partially supported by a contract between the Federal University of Paraná and the Cooperativa Paranaense de Energia Elétrica.

\section{REFERENCES}

FELÍCIO-FERNANDES, G., SOUZA-MOSIMANN, R. M. \& MOREIRA-FILHO, H., 1994, Diatomáceas no rio Tavares, manguezal do rio Tavares, Florianópolis, Santa Catarina, Brasil. I. Ordem Centrales. Insula, 23: 35-90.

FERNANDES, L. F., SOUZA-MOSIMANN, R. M. \& FELÍCIO-FERNANDES, G., 1990, Diatomáceas (Bacillariophyceae) do rio Ratones, Florianópolis, Santa Catarina, Brasil. I. Baixo curso e estuário. Insula, 20: 11-112.

FERNANDES, L. F., BRANDINI, F. P., GUTSEIT, K. S., FONSECA, A. L. \& PELLIZZARI, F. M., 1999, Benthic diatoms growing on glass slides in the Paranaguá Bay, Southern Brazil: taxonomic structure and seasonal variation. Insula, 30: 00-00 (in press).

FERNANDES, L. F., (submitted), New observations on the frustule structures of Eupodiscus radiatus J. W. Bailey, with comments on the Genus Fryxelliella A. K. S. K. Prasad. Hydrobiol.

FOGED, N., 1975, Some littoral diatoms from the coast of Tanzania. Bibl. Phycolog., 16: 1-127.

GLEZER, Z. I., 1975, K revizii roda Triceratium Ehrenberg sensu Hustedt 1930 (Bacillariophyta). Bot. Zh. SSSR, 60: 1304-1310.

HASLE, G. R. \& FRYXELL, G. A., 1970, Diatoms: cleaning and mounting for light and electron microscopy. Trans. Am. Microsc. Soc., 89(4): 469-474.

HOBAN, M. A., 1979, Morphology, life histories and systematics of selected genera of biddulphioid diatoms. PhD. Dissertation, The University of Texas at Austin, USA.

HOBAN, M. A., 1983, Biddulphioid diatoms. II: the morphology and systematics of the pseudocellate species, Biddulphia biddulphiana (Smith) Boyer, B. alternans (Bailey) Van Heurck, and Trigonium arcticum (Brightwell) Cleve. Bot. Mar., 26: 271-284.

HUSTEDT, F., 1927-1966, Die Kieselalgen Deutschlands, Österreichs und der Schweiz mit Berücksichtigung der übrigen Ländern Europas sowie der angrenzenden Meeresgebite. In: L. Rabenhorst Kryptogamenflora, 7(3): 1-816. 
MILLER, W. I. \& COLLIER, A., 1978, Ultrastruscture of the frustule of Triceratium favus (Bacillariophyceae). $J$. Phycol., 14: 56-62.

PRASAD, A. K. S. K., RIDDLE, K. A. \& LIVINGSTON, R J., 1997, Fine structure, taxonomy, and systematics of the centric diatom Fryxelliella gen. nov. (Eupodiscaceae, Bacillariophyta) having a new valve structure, the circumferential marginal tube, with descriptions of $F$. floridana sp. nov. and $F$. inconspicua (Rattray) comb. nov. Phycologia, 36(4): 305-323.

RICARD, M., 1987, Diatomophycées. In: A. Sournia, A. 1987, Atlas du phytoplankton marin. Vol. II, ed. CNRS, Paris, 297p.

ROSS, R. \& SIMS, P. A., 1971, Generic limits in the Biddulphiaceae as indicated by the scanning electron microscope. In: V. H. Heywood (ed.), Scanning electron microscopy: systematic and evolutionary applications. Academic Press, London, pp. 155-177.

ROSS, R. \& SIMS, P. A., 1972, The fine structure of the frustule in centric diatoms: a suggested terminology. $\mathrm{Br}$. Phycol. J., 7: 139-163.

ROSS, R. \& SIMS, P. A., 1973, Observations on family and generic limits in the Centrales. Nova Hedwig., Beih., 45 . 97-128.

ROSS, R., COX, E. J., KARAYEVA, N. I., MANN, D. G., PADDOCK, T. B. B., SIMONSEN, R. \& SIMS, P. A. 1979, An amended terminology for the siliceous components of the diatom cell. Nova Hedwig., Beih., 64: 513533 .

ROUND, F. E., CRAWFORD, R. M. \& MANN, D. G., 1990, The diatoms. Biology and morphology of the genera. Cambridge University Press, Cambridge, 747p.
SAR, E., 1989, Ultrastructure of Odontella rostrata (Hustedt) Simonsen, a new record for the South Atlantic Ocean. Bot. Mar., 32: 187-189.

SCHMIDT, A., 1885, Atlas der Diatomaceen-Kunde. Series II, Tafel 49-96. O. R. Reisland, Leipzig.

SIMONSEN, R., 1979, The diatom system: ideas on phylogeny. Bacillaria, 2: 9-71.

SIMS, P. A. \& ROSS, R., 1990, Triceratium pulvinar and T. unguiculatum, two confused species. Diatom Res., (5): 155-169.

SOUZA-MOSIMANN, R. M. de, 1984, Estudo preliminar das diatomáceas (Chrysophyta-Bacillariophyceae) na região de Anhatomirim, Santa Catarina, Brasil. Insula, 14: 2-46.

SOUZA-MOSIMANN, R. M. de, 1985, Contribuição ao conhecimento das diatomáceas (Chrysophyta-Bacillariophyceae) em algumas estações localizadas na Baía Sul, Florianópolis, Santa Catarina, Brasil. Insula, 15: 3-33.

SOUZA-MOSIMANN, R. M. de, 1988, Estudo preliminar das diatomáceas (Chrysophyta-Bacillariophyceae) da Baía Norte, Florianópolis, Santa Catarina, Brasil. Insula, 18: 23-74.

VANLANDINGHAN, S. L., 1978, Catalogue of the fossil and recent genera and species of diatoms and their synonyms. Part VII. Rhoicosphenia through Zygoceros J. Cramer Verlag, Vaduz, pp. 3606-4241. 